\title{
LARINGOTRAQUEÍTE INFECCIOSA DAS AVES: DIAGNÓSTICO LABORATORIAL, CARACTERIZAÇÃO VIRAL E MEDIDAS DE CONTROLE EM UM SURTO EM AVES DE POSTURA COMERCIAL EM SÃO PAULO, BRASIL
}

\author{
(AVIAN INFECTIOUS LARYNGOTRACHEITIS: LABORATORIAL DIAGNOSTIC, VIRAL \\ CHARACTERIZATION AND CONTROL MEASURES IN AN OUTBREAK IN COMMERCIAL LAYING HENS \\ OF SAO PAULO, BRAZIL)

\section{R. L. LUCIANO ${ }^{*}$, M. R. BUIM ${ }^{2}$, C. DEL FAVA ${ }^{3}$, R. HARAKAVA ${ }^{4}$, M. M. ISHIZUKA ${ }^{5}$, F.G. BUCHALA $^{6}$}

A laringotraqueite infecciosa aviária (LTI) é um patógeno respiratório causado por Herpesviridae, Gallid herpesvirus 1. A doença é responsável por perdas econômicas na produção avícola. Os objetivos deste relatório foram comparar as técnicas de diagnóstico, ELISA e PCR, realizando a caracterização molecular do vírus da LTI, descrever o diagnóstico epidemiológico e as medidas profiláticas aplicadas durante um surto de LTI que ocorreu em Guatapará, São Paulo, Brasil. De dezembro de 2010 a novembro de 2011, oitenta e três amostras combinadas provenientes de bandos de galinhas poedeiras comerciais foram analisados por meio de ELISA e PCR. Destes, quarenta e cinco amostras foram submetidas ao exame histopatológico. Medidas oficiais de controle foram realizadas em duas etapas: fase preliminar (diagnóstico epidemiológico através da aplicação de um questionário específico para orientar o planejamento de medidas profiláticas inespecíficos de biossegurança) e fase de execução, com a concepção de instrumentos legais para delimitar a zona infectada (educação sanitária de todos os agricultores e procedimentos de biossegurança, vigilância passiva, supervisão oficial de todas as atividades e autorização para a vacina TCO). Trinta e duas amostras foram positivas na PCR (38,55\%), utilizando um gene ICP4 (688 pb). Além disso, o DNA das 12 amostras de campo foi sequenciado, mostrando diferentes perfis de duas cepas de vacinas comerciais (CEO e TCO). Aves seropositivas foram detectadas por ELISA em 98,79 \% das amostras. A histopatologia revelou infiltrados inflamatórios linfoplasmocíticos, associados com a presença de células sinciciais com ou sem inclusões eosinofílicas intranucleares em $31,1 \%$ das amostras. Estes resultados permitem inferir que o ELISA foi altamente sensível na detecção de anticorpos LTI, enquanto o PCR e a histopatologia foram específicos na identificação do vírus e das lesões características de LTI, respectivamente. O programa oficial é importante para obter a colaboração dos agricultores para tomar as medidas de biossegurança que podem prevenir a ocorrência de novos casos de LTI. Além disso, os procedimentos laboratoriais são importantes para apoiar a adoção de medidas de controle pelo Programa Oficial de Sanidade Aviária.

\footnotetext{
${ }^{1 *}$ Mestre - Centro Avançado de Pesquisa Tecnológica do Agronegócio Avícola - Instituto Biológico. E-mail: rluciano@biologico.sp.gov.br

${ }^{2}$ Doutor - Unidade de Pesquisa e Desenvolvimento de Bastos - Instituto Biológico

${ }^{3}$ Doutor - Centro de Pesquisa e Desenvolvimento de Sanidade Animal - Instituto Biológico

${ }^{4}$ Doutor - Centro de Pesquisa e Desenvolvimento de Sanidade Vegetal - Instituto Biológico

${ }^{5}$ Doutor - Faculdade de Medicina Veterinária - USP

${ }^{6}$ Pós-doutor - Coordenadoria de Defesa Agropecuária do Estado de São Paulo
} 
${ }^{1 *}$ Mestre - Centro Avançado de Pesquisa Tecnológica do Agronegócio Avícola - Instituto Biológico. E-mail: rluciano@biologico.sp.gov.br ${ }^{2}$ Doutor - Unidade de Pesquisa e Desenvolvimento de Bastos - Instituto Biológico

${ }^{3}$ Doutor - Centro de Pesquisa e Desenvolvimento de Sanidade Animal - Instituto Biológico

${ }^{4}$ Doutor - Centro de Pesquisa e Desenvolvimento de Sanidade Vegetal - Instituto Biológico

${ }^{5}$ Doutor - Faculdade de Medicina Veterinária - USP

${ }^{6}$ Pós-doutor - Coordenadoria de Defesa Agropecuária do Estado de São Paulo 